\title{
Combination treatment with valsartan and amlodipine intensifies evening suppression of Bmal1 clock gene in kidneys of spontaneously hypertensive rats Kombinovaná liečba valsartanom a amlodipínom zvyšuje večernú supresiu Bmal1 génu v obličkách spontánne hypertenzných potkanov
}

Abstract Blood pressure (BP) rhythm is exhibited in a circadian pattern regulated by complex system of endogenous factors. Administration of pharmacological treatment at the right time can influence the efficacy of treatment; but while kidneys play significant role in BP regulation, little is known about their role in chronopharmacotherapy. This study aimed to compare differences between morning and evening dosing with valsartan and amlodipine combination in both short-term and long-term settings and to elucidate the role of kidneys in chronopharmacology. Spontaneously hypertensive rats aged between 8 and 10 weeks were daily treated with $10 \mathrm{mg} / \mathrm{kg}$ of valsartan and $4 \mathrm{mg} / \mathrm{kg}$ of amlodipine, either in the morning or in the evening with treatment duration of 1 and 6 weeks. After short-term treatment, only morning treatment group demonstrated significantly better outcomes in terms of BP control when compared to placebo. After long-term treatment, both treatment groups gained superior results in BP control against placebo; however, no significant difference was seen between morning and evening treatment. Interestingly, clock gene expression in kidney has been significantly modulated only in the evening-treated groups, with treatment intensifying the reduced Bmal1 levels, while Per2 expression was less altered. However, no direct relation with the outcomes of the therapy has been observed, suggesting that pharmacotherapy may serve as an independent modulator of peripheral circadian clock in the kidney.

Slovak Rytmus krvného tlaku má charakteristickú cirkadiánnu štruktúru, ktorá je podmienená komplexným systémom endogénnych abstract faktorov. Podávanie farmakologickej liečby v správnom čase môže mat' vplyv na účinnost' liečby, úloha obličiek, ktoré významne regulujú tlak krvi, je však v chronofarmakoterapii hypertenzie málo prebádaná. Ciel'om tejto práce bolo porovnat' rozdiely v účinnosti medzi ranným a večerným podávaním kombinácie valsartanu s amlodipínom pri krátkodobej aj dlhodobej liečbe a objasnit’ vplyv obličiek v chronofarmakológii. Spontánne hypertenzným potkanom vo veku 8-10 týždňov bol denne podávaný valsartan v dávke $10 \mathrm{mg} / \mathrm{kg}$ a amlodipín v dávke $4 \mathrm{mg} / \mathrm{kg}$, bud' ráno alebo večer $\mathrm{s}$ dĺžkou liečby 1 a 6 týždňov. Po krátkodobej liečbe sa iba pri rannom podávaní podarilo preukázat významné rozdiely oproti placebu v znížení hodnôt krvného tlaku. Po dlhodobej liečbe sa pri oboch liečených skupinách dosiahli lepšie výsledky v porovnaní s placebom, medzi večernou a rannou liečbou však už nebol pozorovaný významný rozdiel. Expresia hodinových génov v obličkách bola významné modulovaná iba pri večernej liečbe, pričom sa zvýšila potlačená hladina Bmal1, zatial' čo expresia Per2 bola ovplyvnená v menšej miere. Vplyv na expresiu hodinových génov však nemal preukázatel'nú koreláciu s výsledkami liečby, čo naznačuje, že farmakoterapia by mohla pôsobit' na expresiu periférnych hodinových génov v obličkách nezávisle od signalizačnej dráhy, ktorou je sprostredkované zníženie tlaku a redukcia hypertrofie lavej komory.

Keywords Chronotherapy-valsartan-amlodipine-spontaneously hypertensive rats (SHR)-Bmal1-clock genes

Klúčové Chronoterapia-valsartan-amlodipín-spontánne hypertenzné potkany (SHR)-Bmal1-hodinové gény

slová:

\section{INTRODUCTION}

Cardiovascular function, including blood pressure, displays daily rhythms, providing the basis for the formation of chronopharmacology, i.e.an implementation of chronobiology into pharmacodynamics and pharmacokinetics. Indeed, dosing time-dependent differences in efficacy of antihypertensive treatment have been reported in humans

*E-mail:petar.potucek@gmail.com

(c) European Pharmaceutical Journal 
(Hermida et al., 2003) and in rat (Liu et al., 2011), a primarily nocturnal animal. Data available from combinational therapy are still very limited (Potucek \& Klimas, 2013), but it is generally assumed that chronopharmacological profiles of each drug might contribute to the dosing-time-dependent influences on efficacy.

Oscillations in cardiovascular functions are strictly controlled by an endogenous oscillator, the circadian clock pathway. In mammals, specific clock genes constitute the core of the molecular clock (Takahashi et al., 2008). These genes are involved in interlocking positive and negative transcriptional and translational feedback loops that drive the oscillation of circadian gene expression in individual cells. The rhythmic transcriptional enhancement of various genes is governed by heterodimer of two transcription factors, circadian locomotor output cycles protein kaput (CLOCK) and brain and muscle Arnt-like protein-1 (BMAL1). The CLOCK-BMAL1 heterodimer activates the transcription homologs of Period (Per)1, Per2, Per3 and Cryptochrome (Cry)1, Cry2. PER and CRY proteins then translocate back into the nucleus and inhibit the activity of CLOCK-BMAL1, comprising the negative feedback limb of the circadian clock loop, resulting in the downregulation of its own expression. Outside of the clock loop (i.e. without feedback on CLOCK/BMAL1), the heterodimer controls cellular physiology and biochemical processes through output genes in a time-of-day-dependent manner.

Among core genetic constituents, Bmal1 and Per2 have been identified to play a critical role in the circadian regulation of cardiovascular function, particularly of BP, with a causative role in the development of hypertension (Woon et al., 2007; Richards et al., 2014). Although a number of studies have observed the influence of circadian clock on cardiac function, its impact on kidneys is less explored. In this study, we tested the influence of morning or evening administration of combination of antihypertensives on systolic blood pressure and on renal expression of Bmal1 and Per2.

\section{METHODS}

\section{Experimental design}

We used eight-week-old male SHRs (Department of Toxicology and Laboratory Animal breeding (SAS, Dobra Voda, Slovak Republic). They were maintained under a constant environment with a controlled light/dark cycle for 2 weeks before the experiment. Valsartan and amlodipine besylate (a kind gift from Novartis, Ireland) were dispersed in a $0.5 \%$ solution of methylcellulose. The same vehicle was used for control groups as a placebo treatment. All experimental procedures involving the use of experimental animals were approved by the State Veterinary and Food Administration of the Slovak Republic and by the Ethics Committee of the Faculty of Pharmacy, Comenius University in Bratislava.

We performed two experiments with different duration: 1 week and 6 weeks. Animals were randomized into groups based on the kind of treatment (AV - amlodipine+valsartantreated; Con - controls receiving placebo). These were divided into two sub-groups based on the time of treatment ( $\mathrm{M}$ - morning; $\mathrm{E}$ - evening). Animals in the AV groups were daily given $10 \mathrm{mg} / \mathrm{kg}$ dose of valsartan and $4 \mathrm{mg} / \mathrm{kg}$ dose of amlodipine by oral gavage in the morning between 7 and 8 a.m. and in the evening between 7 and 8 p.m. The same schedule was used in placebo-treated controls. Dosage was adjusted to actual body weight twice a week.

\section{Systolic BP measurements and termination}

At the end of experimental treatments, arterial systolic blood pressure (sBP), as a measure of hypertension was measured prior to daily treatment by the tail-cuff plethysmographic method in pre-trained conscious animals pre-warmed in thermostatic cages. Measurements were repeated several times and the mean of six consecutive values after stabilization was taken. Twenty-four hours after the final dose (i.e. morning or evening, respectively), animals were sacrificed and the left kidney was removed and cortex was prepared and used for further investigation.

\section{RNA isolation and RT-PCR}

We studied the mRNA levels of two crucial circadian genes Bmal 1 and Per 2 in renal cortex by real-time PCR reaction. Tissue samples were homogenized in liquid nitrogen and total RNA was isolated by phenol/chloroform extraction (TriReagent ${ }^{\circledR}$, Sigma Aldrich, USA). The quality of isolated RNA was verified by agarose gel electrophoresis and spectrophotometric analysis (NanoDropND-1000, Thermo Scientific, USA). Two micrograms of total RNA were reverse-transcribed using high-capacity cDNA Reverse Transcription Kit with RNAse inhibitor $^{\circledast}$ (Applied Biosystems, USA). Real-time PCR (StepOne Plus System, Applied Biosystems, USA) was performed using SYBR Select Master Mix (Applied Biosystems, USA). The results were normalized to the expression of endogenous reference genes (Beta-2 microglobulin, B2m; Hprt1, hypoxanthine phosphoribosyltransferase 1) and calibrated to the control group. The following primer sequences were used: Bmal1 (forward: 'GCACTCACACATGGTTCCAC', reverse: 'CATTCCGCAAGGTGTCCTAT'), Per2 (forward: 'GCACAAAGTCAGGGTAGGCC', reverse: 'GCATCAGTAGCCGGTGGATT'), B2m (forward: 'ATGGAGCTCTGAATCATCTGG', reverse: 'AGAAGATGGTGTGCTCATTGC') and Hprt1 (forward: 'CAGCTTCCTCCTCAGACCGCTTT', reverse: 'TCACTAATCACGACGCTGGGACTG'). All primers (SigmaAldrich, USA) were designed by Primer3 version 0.4.0 into intron/exon boundaries to avoid the amplification of genomic DNA. All primers were verified to yield a single PCR product with the correct molecular weight and the absence of signal was confirmed when reverse transcription was omitted (Radik et al., 2016). 
Table 1. Relative $m R N A$ levels of Bmal1 and Per2 in kidneys of controls (Con) and amlodipine+valsartan (AV)-treated rats, respectively. Values are mean $\pm S D\left(n=10-14\right.$ per group; ${ }^{*} P<.05$ vs. Con $)$

\begin{tabular}{|c|c|c|c|c|c|}
\hline \multirow{2}{*}{ Clock gene } & \multirow{2}{*}{ Treatment duration } & \multicolumn{2}{|c|}{ Morning } & \multicolumn{2}{c|}{ Evening } \\
\cline { 2 - 6 } & & Con & AV & Con & $0.08 \pm 0.10^{*}$ \\
\hline \multirow{2}{*}{ Bmal1 } & 1 week & $1.00 \pm 0.12$ & $1.05 \pm 0.13$ & $0.29 \pm 0.10$ & $0.16 \pm 0.02^{*}$ \\
\cline { 2 - 6 } & 6 weeks & $1.00 \pm 0.05$ & $1.11 \pm 0.03$ & $0.29 \pm 0.02$ & $1.16 \pm 0.24$ \\
\hline \multirow{2}{*}{ Per2 } & 1 week & $1.00 \pm 0.12$ & $0.93 \pm 0.06$ & $1.03 \pm 0.09$ & $1.80 \pm 0.20^{*}$ \\
\cline { 2 - 6 } & 6 weeks & $1.00 \pm 0.11$ & $0.97 \pm 0.09$ & $1.03 \pm 0.11$ & \\
\hline
\end{tabular}

\section{Statistical analysis}

All variables are reported as mean \pm standard deviation (SD) or standard error of the mean (SEM). Means were compared using ANOVA with subsequent Tukey's HSD multiple comparison test for normally distributed data or KruskalWallis test followed by pairwise Wilcoxon test with HolmBonferroni correction for non-parametric data, with $p<0.05$ considered as statistically significant. Mean PCR efficiency estimates (E) per amplicon and quantification cycle (Cq) values per sample were determined with LinRegPCR software (version 2015.0) and efficiency corrected relative expression ratios were calculated (all reactions had $\mathrm{E}>1.8$ and $\mathrm{Cq}<35$ ). Data were handled by GraphPad Prism (GraphPad Software, Inc., version 6)

\section{RESULTS}

Following 1-week treatment, we observed reduction of sBP in the morning but not in the evening dosing group, while at the of the 6-week period, treatment was efficient against placebo in both treated groups (Fig. 1).

As expected, mRNA expressions of Bmal1 in renal cortex were suppressed in the evening (Tab. 1). Interestingly, evening treatment intensified the reduced Bmal1 levels after one as well as after 6 weeks of therapy. Per2 expression was less altered, and we found significantly increased mRNA expression only in the evening-treated group (Tab. 1).

\section{DISCUSSION}

Chronopharmacological studies comparing morning and evening dosing of amlodipine+valsartan combination conducted so far have given contradictory results (Hermida et al., 2010; Asmar et al., 2011). In our study, comparison against placebo group revealed that BP control was established faster with morning dosing, but no difference was seen between morning and evening dosing after long-time treatment. So while the long-term treatment with the combination of antihypertensives was demonstrated to be equal regardless of administration time, morning dosing (i.e. during inactive period of rat) exhibited accelerated onset of action and the efficacy of the treatment was established earlier than with the evening dosing (i.e. during active period of rat).
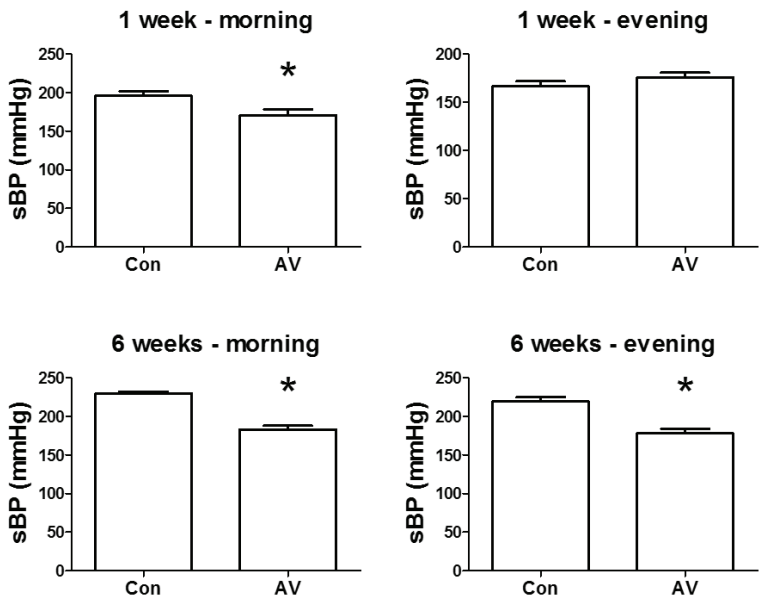

Figure 1. Systolic blood pressures of SHRs treated for 1 week or 6 weeks with placebo (Con) or valsartan +amlodipine combination $(A V)$. Values are mean \pm SEM $\left(n=10-14\right.$ per group; ${ }^{*} P<.05$ vs. corresponding Con)

In SHR model, abnormalities in the expressions of clock genes are limited to hypertrophied left ventricles as concurrently to significant differences in the left ventricular levels of Bmal1 and Per2 (Naito et al., 2003) and lack of significant alterations in clock gene expression were reported in aortas and kidneys in SHRs when compared to normotensive rats (Naito et al., 2003; Cui et al., 2011). Consequently, studies pay less attention to peripheral circadian clock pathway in kidneys during the progression of hypertension, though kidneys are crucial modulators of blood pressure (Vavrinec et al., 2011; Ulu et al., 2013; Vavrinec et al., 2013). Indeed, the hypertensive renal injury occurs several months later than the development of hypertension and left ventricular hypertrophy in SHRs (Braun et al., 2013; Klimas et al., 2015). However, we observed antihypertensive treatment-induced alterations already in young SHRs, which suggest that treatment might alter the circadian clock independently of disease development in the kidneys of SHRs. Although the observed effect of antihypertensive drugs on circadian clock pathway seems to be unspecific, it may have significant influence on the both therapeutic outcome as well as safety of particular drugs. Whether this action provides benefits or not is related to therapeutic failure in patient subpopulations, which requires further investigation. 


\section{CONCLUSION}

In conclusion, we obtained evidence that chronopharmacological effect of amlodipine and valsartan combination observed in short-term treatment was diminished in long-term settings. Our results provided experimental evidence supporting the idea that the combination therapy of valsartan and amlodipine is lacking significant chronopharmacological properties in long-term treatment, while in acute treatment, this combination might be more beneficial when administered during inactive phase. Additionally, our findings showed that the combination of valsartan and amlodipine influences circadian clock pathway in kidneys independently from sBP, i.e. pharmacotherapy may serve as an independent modulator of circadian clock. Still, it remains to be clarified whether modulation of circadian clock contributes someway to the outcome of treatment. If yes, this would further support the concept of the optimization of antihypertensive treatment by timing along the circadian scale.

\section{References}

[1] Asmar R, Gosse P, Quere S, Achouba A. Efficacy of morning and evening dosing of amlodipine/valsartan combination in hypertensive patients uncontrolled by $5 \mathrm{mg}$ of amlodipine. Blood Press Monit. 2011;16(2):80-86.

[2] Braun MC, Herring SM, Gokul N et al. Hypertensive renal disease: susceptibility and resistance in inbred hypertensive rat lines. J Hypertens. 2013;31(10):2050-2059.

[3] Cui H, Kohsaka A, Waki H, Bhuiyan ME, Gouraud SS, Maeda M. Metabolic cycles are linked to the cardiovascular diurnal rhythm in rats with essential hypertension. PLoS One. 2011;6(2):e17339.

[4] Hermida RC, Ayala DE, Fontao MJ, Mojon A, Fernandez JR. Chronotherapy with valsartan/amlodipine fixed combination: improved blood pressure control of essential hypertension with bedtime dosing. Chronobiol Int. 2010;27(6):1287-1303.

[5] Hermida RC, Calvo C, Ayala DE et al. Administration timedependent effects of valsartan on ambulatory blood pressure in hypertensive subjects. Hypertension.2003;42(3):283-290.

[6] Klimas J, Olvedy M, Ochodnicka-Mackovicova K et al. Perinatally administered losartan augments renal ACE2 expression but not cardiac or renal Mas receptor in spontaneously hypertensive rats. J Cell Mol Med. 2015;19(8):1965-1974.

[7] Liu Y, Ushijima K, Ohmori M et al. Chronopharmacology of angiotensin II-receptor blockers in stroke-prone spontaneously hypertensive rats. J Pharmacol Sci. 2011;115(2):196-204.

[8] Naito $Y$, Tsujino T, Kawasaki D et al. Circadian gene expression of clock genes and plasminogen activator inhibitor-1 in heart and aorta of spontaneously hypertensive and Wistar-Kyoto rats. J Hypertens. 2003;21(6):1107-1115.

[9] Potucek P, Klimas J. Chronotherapy of hypertension with combination treatment. Pharmazie. 2013;68(12):921-925.
[10] Radik M, Doka G, Malikova E, Krenek P, Klimas J. Voluntary exercise and testosterone therapy caused increase in percentage of Myh6 and expression of oxidative stress marker Cybb in left ventricles of rats. Eur Pharm J. 2016;63(1):12-15.

[11] Richards J, Diaz AN, Gumz ML. Clock genes in hypertension: novel insights from rodent models. Blood Press Monit. 2014;19(5):249254.

[12] Takahashi JS, Hong HK, Ko CH, McDearmon EL. The genetics of mammalian circadian order and disorder: implications for physiology and disease. Nat Rev Genet.2008;9(10):764-775.

[13] Ulu N, Mulder GM, Vavrinec $P$ et al. Epidermal growth factor receptor inhibitor PKI-166 governs cardiovascular protection without beneficial effects on the kidney in hypertensive 5/6 nephrectomized rats. J Pharmacol Exp Ther. 2013;345(3):393403.

[14] Vavrinec P, Henning RH, Goris M, Landheer SW, Buikema H, van Dokkum RP. Renal myogenic constriction protects the kidney from age-related hypertensive renal damage in the FawnHooded rat. J Hypertens. 2013;31(8):1637-1645.

[15] Vavrinec $P$, van Dokkum RP, Goris M, Buikema H, Henning RH. Losartan protects mesenteric arteries from ROS-associated decrease in myogenic constriction following 5/6 nephrectomy. J Renin Angiotensin Aldosterone Syst. 2011;12(3):184-194.

[16] Woon PY, Kaisaki PJ, Braganca J et al. Aryl hydrocarbon receptor nuclear translocator-like (BMAL1) is associated with susceptibility to hypertension and type 2 diabetes. Proc Natl Acad Sci U S A. 2007;104(36):14412-14417. 